\title{
Bi-Functional Organophosphorus Extractants and Computational Modeling for Copper(II) and Zinc(II) Extraction
}

\author{
Kousuke Araki, Kazuya Uezu, Masahiro Goto ${ }^{\dagger}$ and Shintaro FuruSaKI \\ Department of Chemical Systems and Engineering, Graduate School of Engineering, Kyushu University, \\ Hakozaki, Fukuoka 812-8581, Japan
}

\begin{abstract}
Novel bi-functional extractants, which possess two phosphonic groups on both sides of the extractants, have been synthesized for the separation of $\mathrm{Zn}(\mathrm{II})$ and $\mathrm{Cu}(\mathrm{II})$. The separation properties and extractability of the novel extractants were investigated using the liquid-liquid extraction technique. These bi-functional extractants provide a high selectivity towards $\mathrm{Zn}$ (II) over $\mathrm{Cu}$ (II) compared to that of monoacidic phosphorus extractant as an analog. We discussed the extraction behavior of the bi-functional extractants with a computational modeling by means of semi-empirical molecular orbital methods. The calculation suggests that the length of the spacer is one of the decisive factors to enhance the selectivity in the bi-functional extractants. The high separation ability for the bi-functional extractants was related to the high energy difference in the heat of formation calculated by computational modeling. The computational simulation was found to be very useful for the design of novel extractants and prediction of their separation performance.
\end{abstract}

Keywords Liquid-liquid extraction, metal separation, computational modeling, computer chemistry, organophosphorus extractant

In the liquid-liquid extraction technology, the extractant is well-known to play a key role for separating target metal ions. The selection of appropriate extractant often decides the success of the extraction process. To date, a lot of extractants have been developed and their extraction properties have been evaluated for a variety of metal ions. ${ }^{1-11}$ In a previous study, we have developed novel bi-functional organophosphorus extractants in which two phosphonic acids were introduced as functional groups in the molecular structure for the separation of rare earth metals. ${ }^{12}$ The result indicated that extraction performance of bi-functional extractants is very sensitive to the molecular structure of the spacer which connects the two functional moieties. In the present study, we applied this novel type of bi-functional extractants to the separation of $\mathrm{Cu}(\mathrm{II})$ and $\mathrm{Zn}(\mathrm{II})$. Since the structures of $\mathrm{Cu}(\mathrm{II})$ and $\mathrm{Zn}$ (II) complexes with a ligand are different from each other, an interesting extraction behavior is expected for the bi-functional extractants. We focused on the difference in the length of the spacer because the spacer length was considered to affect the complex formation of $\mathrm{Cu}$ (II) (square planar) and $\mathrm{Zn}(\mathrm{II})$ (tetrahedral). In this work, three bifunctional organophosphorus extractants which have a different spacer length were prepared, and their extraction performance for $\mathrm{Cu}(\mathrm{II})$ and $\mathrm{Zn}$ (II) was investigated compared to that of a monomeric extractant as an ana$\log$.

$\doteqdot$ To whom correspondence should be addressed.
Recently, computational chemistry attracted much attention for the design of novel extractants. ${ }^{12-16}$ In the field of solvent extraction, interfacial properties of extractants at the oil-water interfaces were discussed on the extraction rate using MD method. ${ }^{17}$ In our study, extraction behavior of the bi-functional extractants for $\mathrm{Cu}(\mathrm{II})$ and $\mathrm{Zn}(\mathrm{II})$ is discussed with computational modeling. Calculated results support the conclusion that the bi-functional organophosphorus extractants show a high selectivity towards $\mathrm{Zn}$ (II) over $\mathrm{Cu}$ (II) compared to that of mono-functional analog. We also demonstrate that the computational modeling is very helpful for predicting extraction behavior and designing new extractants for a target metal ion.

\section{Experimental}

\section{Reagents}

1,4-Butanediol- $O, O^{\prime}$-diphenyl phosphonic acid (abbreviated as BDPA), 1,8-octanediol- $O, O^{\prime}$-diphenyl phosphonic acid (abbreviated as ODPA) and 1,12-dodecanediol- $O, O^{\prime}$-diphenyl phosphonic acid (abbreviated as DDDPA) were synthesized by the procedures described in the following section. A mono-functional extractant, phenyl phosphonic acid mono-2-ethylhexyl ester (abbreviated as 2EHPA), was also synthesized as the analog to discuss the bi-functional effect. Figure 1 shows the molecular structures of the newly developed extractants applied in this study. Analytical grade of 


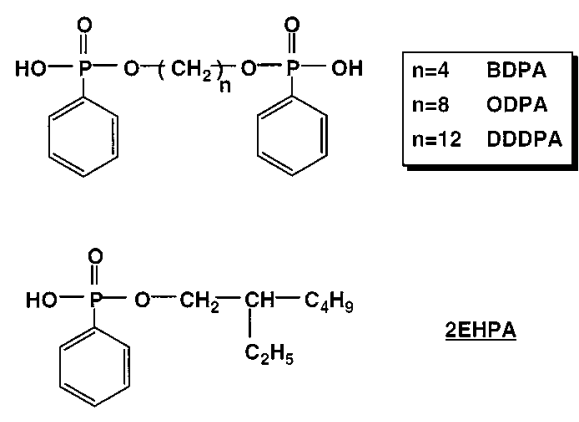

Fig. 1 Molecular structures of extractants synthesized in this study.

chloroform was employed as an organic diluent. Water was purified with a membrane purification system (Millipore; Elix3) after double distillation. Other reagents were of commercially available grades.

\section{Synthesis of bi-functional extractants}

DDDPA was synthesized as follows: Under a nitrogen atmosphere, $56.2 \mathrm{~g}(0.288 \mathrm{~mol})$ of phosphonic dichloride was added to the mixture of $60 \mathrm{~cm}^{3}$ dry tetrahydrofuran and $50 \mathrm{~cm}^{3}$ of pyridine placed in an iced bath. $24.3 \mathrm{~g}$ (0.120 mol) 1,12-dodecanediol dissolved in $130 \mathrm{~cm}^{3}$ dry tetrahydrofuran and dry pyridine was slowly added dropwise to the above solution at $273 \mathrm{~K}$. This mixture was stirred in an iced bath for $48 \mathrm{~h}$, and then poured into $350 \mathrm{~cm}^{3}$ of cold water with ice. Concentrated hydrochloric acid was added to the solution until the $\mathrm{pH}$ of the aqueous solution became between 1 and 2 . Then $300 \mathrm{~cm}^{3}$ of chloroform was added to the acidified solution in order to extract the product. The mixed liquor containing chloroform was stirred for $2 \mathrm{~h}$. The organic phase was separated, washed twice with 250 $\mathrm{cm}^{3}$ of $1 \mathrm{M}$ hydrochloric acid, and dried with anhydrous magnesium sulfate. After the organic phase was evaporated, the final product was obtained. The crude product was finally purified by column chromatography (silica gel, chloroform $/$ methanol=9/1,v/v). DDDPA was characterized as follows: light yellow viscous liquid, yield 95.0\%; IR (neat) $v_{\mathrm{OH}} 2650 \mathrm{~cm}^{-1}, v_{\mathrm{P}=\mathrm{O}}$ and $\delta_{\mathrm{OH}} 2270$ $\mathrm{cm}^{-1}, V_{\mathrm{P}-\mathrm{OR}} 1684 \mathrm{~cm}^{-1} ;{ }^{1} \mathrm{H}-\mathrm{NMR}\left(250 \mathrm{MHz}, \mathrm{CDCl}_{3}\right.$, TMS, $303 \mathrm{~K}) \quad \delta=1.23 \quad(16 \mathrm{H}, \quad \mathrm{m}$, $\left.-\mathrm{O}-\mathrm{CH}_{2}-\mathrm{CH}_{2}-\left(\mathrm{CH}_{2}\right)_{8}-\mathrm{CH}_{2}-\mathrm{CH}_{2}-\mathrm{O}-\right), \delta=1.63(4 \mathrm{H}, \mathrm{m}$, $\left.-\mathrm{O}-\mathrm{CH}_{2}-\mathrm{CH}_{2}-\left(\mathrm{CH}_{2}\right)_{8}-\mathrm{CH}_{2}-\mathrm{CH}_{2}-\mathrm{O}-\right), \delta=3.96(4 \mathrm{H}, \mathrm{m}$, $\left.-\mathrm{O}-\mathrm{CH}_{2}-\mathrm{CH}_{2}-\left(\mathrm{CH}_{2}\right)_{8}-\mathrm{CH}_{2}-\mathrm{CH}_{2}-\mathrm{O}-\right), \delta=7,47(6 \mathrm{H}, \mathrm{m}$, $\mathrm{P}-\mathrm{Ar} H$ ( $m, p$-position)), $\delta=7.80(4 \mathrm{H}, \mathrm{m}, \mathrm{P}-\mathrm{ArH}$ (o-position)), $\delta=8.28(2 \mathrm{H}, \mathrm{s}, \mathrm{P}-\mathrm{OH})$. The elemental constituents of the final product are as follows: $\mathrm{C}, 59.79 \%$, $\mathrm{H}, 7.61 \%$. Calculation for $\mathrm{C}_{24} \mathrm{H}_{36} \mathrm{O}_{6} \mathrm{P}_{2}$ gives: $\mathrm{C}, 59.75$ $\%, \mathrm{H}, 7.52 \%$.

The synthetic steps of ODPA and BDPA are similar to the procedures for synthesizing DDDPA. The elemental constituents of ODPA are as follows: C, $55.40 \%, \mathrm{H}, 6.74 \%$. The calculation for $\mathrm{C}_{20} \mathrm{H}_{28} \mathrm{O}_{6} \mathrm{P}_{2} \cdot 0.05-$ $\mathrm{CHCl}_{3}$ gives: $\mathrm{C}, 55.70 \%, \mathrm{H}, 6.54 \%$. The elemental constituents of BDPA are as follows: C, $49.84 \%, \mathrm{H}$,
5.45\%. The calculation for $\mathrm{C}_{16} \mathrm{H}_{20} \mathrm{O}_{6} \mathrm{P}_{2} \cdot 0.15 \mathrm{CHCl}_{3}$ gives: C, $49.97 \%, \mathrm{H}, 5.23 \%$.

\section{Synthesis of mono-functional extractant, 2EHPA}

Under a nitrogen atmosphere, $5.85 \mathrm{~g}(0.03 \mathrm{~mol})$ of phosphonic dichloride was added to the mixture of 20 $\mathrm{cm}^{3}$ dry tetrahydrofuran and $20 \mathrm{~cm}^{3}$ pyridine placed in an ice bath. A solution of $3.96 \mathrm{~g}(0.03 \mathrm{~mol})$ 2-ethylhexyl alcohol in $80 \mathrm{~cm}^{3}$ dry tetrahydrofuran was slowly added dropwise to the above solution at $273 \mathrm{~K}$. The mixture was stirred in an ice bath for $48 \mathrm{~h}$, and then poured into $350 \mathrm{~cm}^{3}$ of ice water. Concentrated hydrochloric acid was added to the solution until the $\mathrm{pH}$ of aqueous solution becomes between 1 and 2 . Then $300 \mathrm{~cm}^{3}$ chloroform was added to the acidic solution in order to extract the product. The mixed liquor containing chloroform was stirred for $2 \mathrm{~h}$. The organic phase was separated, washed twice with $250 \mathrm{~cm}^{3}$ hydrochloric acid $(1 \mathrm{M})$, and dried with anhydrous magnesium sulfate. After the organic phase was evaporated, the final product was obtained. The crude product was finally purified by column chromatography (silica gel, chloroform/methanol=9/1,v/v). 2EHPA was characterized as follows: light yellow liquid, yield $88.8 \%$; IR (neat) $v_{\mathrm{OH}} 2650 \mathrm{~cm}^{-1}, v_{\mathrm{P}=\mathrm{O}}$ and $\delta_{\mathrm{OH}} 2280 \mathrm{~cm}^{-1}, v_{\mathrm{P}-\mathrm{OR}}$ $1675 \mathrm{~cm}^{-1}$; ${ }^{1} \mathrm{H}-\mathrm{NMR}\left(250 \mathrm{MHz}, \mathrm{CDCl}_{3}\right.$, TMS, $\left.303 \mathrm{~K}\right)$ $\delta=0.87\left(6 \mathrm{H}, \mathrm{t},-\mathrm{CH}_{2}-\mathrm{CH}_{3}\right), \delta=1.24\left(8 \mathrm{H}, \mathrm{m},-\mathrm{CH}_{2^{-}}\right)$, $\delta=1.52\left(1 \mathrm{H}, \mathrm{m},-\mathrm{CH}_{2}-\mathrm{CH}\left(\mathrm{C}_{2} \mathrm{H}_{5}\right)-\mathrm{C}_{4} \mathrm{H}_{9}\right), \delta=3.90(2 \mathrm{H}, \mathrm{m}$, $\left.-\mathrm{O}-\mathrm{CH}_{2}-\mathrm{CH}\left(\mathrm{C}_{2} \mathrm{H}_{5}\right)-\mathrm{C}_{4} \mathrm{H}_{9}\right), \delta=7.40(3 \mathrm{H}, \mathrm{m}, \mathrm{P}-\mathrm{Ar} H(m$, $p$-position)), $\delta=7.78(2 \mathrm{H}, \mathrm{m}, \mathrm{P}-\mathrm{Ar} H$ (o-position)), $\delta=12.64(1 \mathrm{H}, \mathrm{s}, \mathrm{P}-\mathrm{OH})$. The elemental constituents of 2EHPA are as follows: C, $63.23 \%, \mathrm{H}, 8.93 \%$. Calculation for $\mathrm{C}_{14} \mathrm{H}_{23} \mathrm{O}_{3} \mathrm{P}$ gives: $\mathrm{C}, 62.21 \%, \mathrm{H}, 8.58 \%$

\section{Solvent extraction procedure}

Organic solutions were prepared by dissolving BDPA, ODPA, DDDPA or 2EHPA with chloroform. Aqueous solutions contain $0.1 \mathrm{mM}$ of each metal cation, whose initial $\mathrm{pH}$ was adjusted with the buffer system: $100 \mathrm{mM}$ nitric acid and $100 \mathrm{mM}$ acetic acidsodium acetate. The synthetic pregnant solution at each experimental stage contained two different metals, namely: $\mathrm{Zn}(\mathrm{II})$ and $\mathrm{Cu}(\mathrm{II})$, or $\mathrm{Co}(\mathrm{II})$ and $\mathrm{Ni}(\mathrm{II})$. A mixture of equal volumes $(5 \mathrm{ml})$ of the organic solution and the aqueous solution was shaken in a thermostatted water bath at $303 \mathrm{~K}$ for $24 \mathrm{~h}$. After phase separation, $\mathrm{pH}$ and metal concentration in the aqueous phase were measured with a $\mathrm{pH}$ meter (TOA; HM-60S) and an atomic absorption spectrophotometer (SHIMADZU; AA-6700), respectively.

\section{ESR spectroscopy}

An aqueous solution containing $0.2 \mathrm{mM} \mathrm{Cu}$ (II) was prepared, its $\mathrm{pH}$ was adjusted to 5 with acetate buffer. The chloroform solution treated as mentioned above was subjected to ESR spectroscopy. ESR spectral measurements were performed with a ESR spectrometer (JEOL; JES-FE1XG) at the X-band frequency (9.21598 $\mathrm{GHz})$ at $77 \mathrm{~K}$. 
Table 1 Dependencies on chemical species and extraction equilibrium constants for $\mathrm{Zn}$ and $\mathrm{Cu}$

\begin{tabular}{|c|c|c|c|c|c|c|c|}
\hline \multirow{2}{*}{ Reagent } & \multirow{2}{*}{$\mathrm{pH}-\log D_{\mathrm{Zn}}$} & \multirow{2}{*}{$\mathrm{pH}-\log D_{\mathrm{Cu}}$} & \multirow{2}{*}[(\mathrm{H}_{2}\mathrm{R})_{2}]{$-\log D_{\mathrm{Zn}}$} & \multirow{2}{*}[(\mathrm{H}_{2}\mathrm{R})_{2}]{$-\log D_{\mathrm{Cu}}$} & \multicolumn{2}{|c|}{$K_{\mathrm{ex}}$} & \multirow{2}{*}{$\begin{array}{c}\text { Separation factor } \\
(\mathrm{Zn} / \mathrm{Cu})\end{array}$} \\
\hline & & & & & $\mathrm{Zn}$ & $\mathrm{Cu}$ & \\
\hline BDPA & 2 & - & 2 & - & $8.8 \times 10^{-1}$ & - & - \\
\hline ODPA & 2 & - & 1 & - & $3.9 \times 10^{-2}$ & - & - \\
\hline DDDPA & 2 & 2 & 1 & 1 & $1.2 \times 10^{-2}$ & $3.2 \times 10^{-6}$ & 3800 \\
\hline \multirow[b]{2}{*}{ Reagent } & \multirow[b]{2}{*}{$\mathrm{pH}-\log D_{\mathrm{Zn}}$} & \multirow[b]{2}{*}{$\mathrm{pH}-\log D_{\mathrm{Cu}}$} & \multirow[b]{2}{*}[(\mathrm{HR})_{2}]{$-\log D_{\mathrm{Zn}}$} & \multirow[b]{2}{*}[(\mathrm{HR})_{2}]{$-\log D_{\mathrm{Cu}}$} & \multicolumn{2}{|c|}{$K_{\mathrm{ex}}$} & Separation factor \\
\hline & & & & & $\mathrm{Zn}$ & $\mathrm{Cu}$ & $(\mathrm{Zn} / \mathrm{Cu})$ \\
\hline 2EHPA & 2 & 2 & 2 & 2 & $8.2 \times 10^{-2}$ & $1.0 \times 10^{-4}$ & 820 \\
\hline
\end{tabular}

\section{Molecular modeling}

Input coordinates were obtained from the graphics package HyperChem Release 5.1 (Hypercube, Inc., Canada). PM3 type of semi-empirical molecular orbital calculations (SMO) of the complex was carried out using MOPAC $93^{18}$ (the convergence criteria for GNORM=0.01 and SCFCRT $=0.00001)$.

\section{Results and Discussion}

\section{Extraction properties of bi-functional extractants}

Figure 2 shows the $\mathrm{pH}$ dependencies of metal extraction for $\mathrm{Zn}$ (II) and $\mathrm{Cu}$ (II) on the analytical concentration of the four extractants. The degree of extraction increased with increasing $\mathrm{pH}$. This result means that the complex formation proceeds through an ionexchange mechanism. All extractants exhibit a high selectivity toward $\mathrm{Zn}$ (II) over $\mathrm{Cu}$ (II) due to the high affinity of the functional phosphonic group to $\mathrm{Zn}$ (II). ${ }^{19}$ However, the bi-functional extractants developed in this study show little extractability for Co(II) and $\mathrm{Ni}(\mathrm{II})$, although the mono-functional extractant analogue possesses a moderate extraction ability to $\mathrm{Co}(\mathrm{II})$, as shown in Fig. 2(d). The extraction ability of organophosphorus extractants to $\mathrm{Cu}$ (II) appears to be reduced by introducing the spacer in the molecular structure. This property of bi-functional extractants results in the enhancement of the selectivity between $\mathrm{Zn}$ (II) and $\mathrm{Cu}(\mathrm{II})$. The above observation suggests that the spacer linking the two functional phosphonic groups restricts the flexibility of the bi-functional extractants, which especially affects the complex formation with a square planar structure.

The dependencies of the distribution ratio $\mathrm{D}$ on $\mathrm{pH}$ and on each chemical species are summarized in Table 1. The pH dependency exhibits the slope of two for $\mathrm{Zn}$ (II) and $\mathrm{Cu}$ (II) with all extractants. It means that complex formation accompanies with the displacement of two hydrogen ions when each divalent cation is extracted.

In the $\mathrm{Zn}$ (II) extraction, the dependency on the extractant concentration exhibits the slope of one for ODPA and DDDPA, while it is two for BDPA and 2EHPA. This result suggests that the extractant which has a shorter spacer needs more extractant molecules to
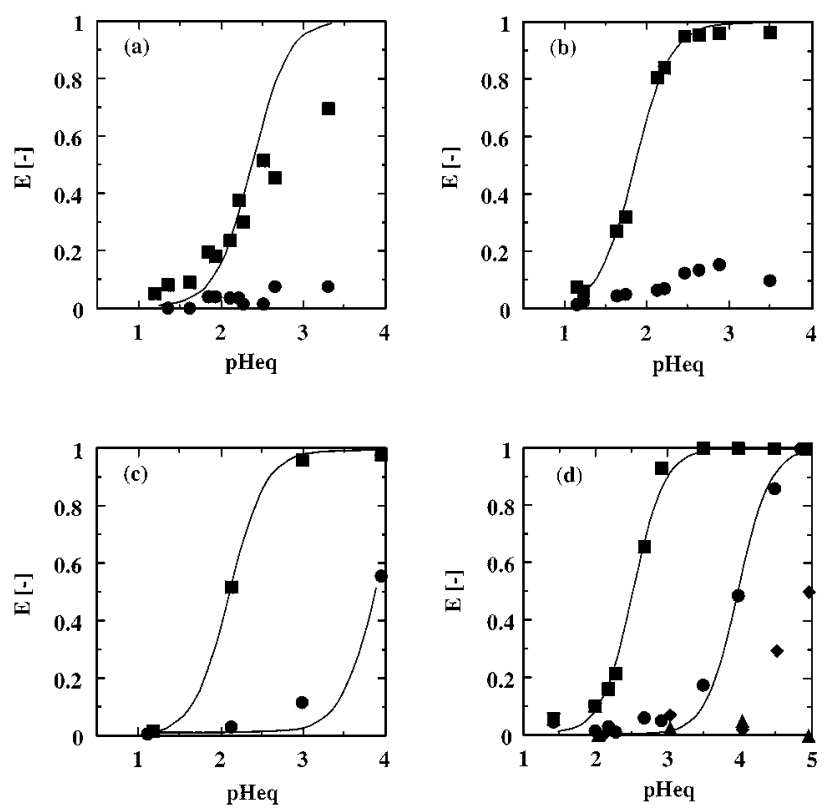

Fig. $2 \mathrm{pH}$ dependencies of extracted ratio for $\mathrm{Zn}(\mathrm{II}), \mathrm{Cu}(\mathrm{II})$, Co(II) and $\mathrm{Ni}$ (II). (a) $10 \mathrm{~mol} / \mathrm{m}^{3}$ BDPA in chloroform; (b) 10 $\mathrm{mol} / \mathrm{m}^{3}$ ODPA in chloroform; (c) $10 \mathrm{~mol} / \mathrm{m}^{3}$ DDDPA in chloroform; (d) $20 \mathrm{~mol} / \mathrm{m}^{3}$ 2EHPA in chloroform. $0.1 \mathrm{~mol} / \mathrm{m}^{3}$ of $\mathrm{Zn}(\bullet), \mathrm{Cu}(\bullet), \mathrm{Co}(\bullet), \mathrm{Ni}(\bullet)$. Solid lines are the calculated lines.

enhance the hydrophobicity of the metal complexes. In the $\mathrm{Cu}(\mathrm{II})$ extraction, the dependency exhibits the slope of one for DDDPA and two for 2EHPA.

It is well-known that an organophosphorus reagents exist as a dimer in an organic solvent. ${ }^{20-26}$ Based on the results described above, the stoichiometry of $\mathrm{Zn}(\mathrm{II})$ and $\mathrm{Cu}$ (II) extraction by BDPA, ODPA, DDDPA and 2EHPA can be expressed by the following equations:

In the case of BDPA for $\mathrm{Zn}$,

$\mathrm{Zn}^{2+}+2\left(\mathrm{H}_{2} \mathrm{~L}\right)_{2}=\mathrm{Zn}(\mathrm{HL})_{2}\left(\mathrm{H}_{2} \mathrm{~L}\right)_{2}+2 \mathrm{H}^{+} \quad: K_{\mathrm{ex}}$

In the case of ODPA or DDDPA for Zn,

$\mathrm{Zn}^{2+}+\left(\mathrm{H}_{2} \mathrm{~L}\right)_{2}=\mathrm{Zn}(\mathrm{HL})_{2}+2 \mathrm{H}^{+} \quad: K_{\mathrm{ex}}$

In the case of DDDPA for $\mathrm{Cu}$ 


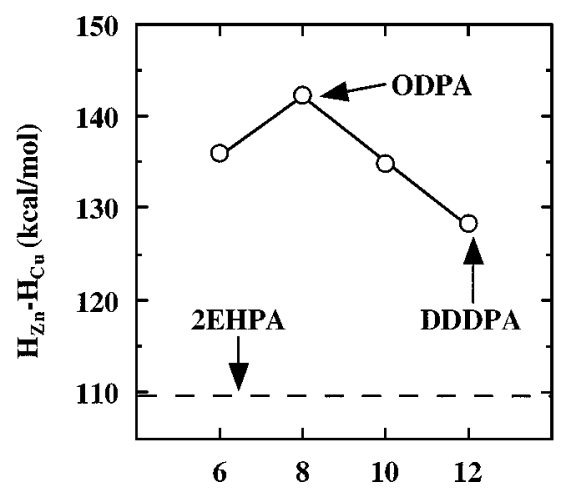

Spacer length (number of carbons)

Fig. 3 A plot of the difference between calculated $H_{\mathrm{Zn}}$ and $H_{\mathrm{Cu}}$ versus the spacer length.

$$
\mathrm{Cu}^{2+}+\left(\mathrm{H}_{2} \mathrm{~L}\right)_{2}=\mathrm{Cu}(\mathrm{HL})_{2}+2 \mathrm{H}^{+} \quad: K_{\mathrm{ex}}
$$

In the case of 2EHPA for $\mathrm{Zn}$ and $\mathrm{Cu}$,

$$
\mathrm{M}^{2+}+2(\mathrm{HL})_{2}=\mathrm{ML}_{2}(\mathrm{HL})_{2}+2 \mathrm{H}^{+} \quad: K_{\mathrm{ex}}
$$

where $\mathrm{M}, \mathrm{H}_{2} \mathrm{~L}$ and $\mathrm{HL}$ denote $\mathrm{Zn}$ or $\mathrm{Cu}$, bi-functional and mono-functional extractants respectively. Extraction equilibrium constants $\left(K_{\mathrm{ex}}\right)$ were defined according to each extraction equilibrium equation (Eqs. $(1)-(4))$. Based on all the experimental results, the $K_{\text {ex }}$ values were calculated and these are summarized again in Table 1. Bi-functional extractants which have a low affinity to $\mathrm{Cu}$ show higher separation factors between $\mathrm{Zn}(\mathrm{II})$ and $\mathrm{Cu}(\mathrm{II})$ than that of monomer analog 2EHPA. In the next section we discuss the extraction behavior, based on the results of computational modeling for the $\mathrm{Zn}$ (II) and $\mathrm{Cu}$ (II) complexes.

\section{Computational modeling}

Recently, computer chemistry has been utilized for designing novel materials. Also, in liquid-liquid extraction technology, several reports in which computational modeling was employed have been published for discussing the stable structure of a metal complex ${ }^{12-16}$ and the extraction mechanism. ${ }^{17}$ In the present work, computational modeling is utilized for evaluating the separation performance of the newly synthesized bi-functional extractants. In a previous paper, we reported that the selectivity of extractants for rare earth metals was strongly related to the energy difference in the complex formation. Hancock et al. ${ }^{27}$ first proposed the QSPR theory for estimating the strain energy for transition metal complexes with polyamines. According to the theory, the increase in the energy of complex formation between $\mathrm{Zn}$ (II) and $\mathrm{Cu}(\mathrm{II})$ complexes is expressed by the following equation:

$$
\Delta H_{\mathrm{Zn}}-\Delta H_{\mathrm{Cu}}=\left(H_{\mathrm{Zncom}}-H_{\mathrm{Cucom}}\right)-\left(H_{\mathrm{Zn}}-H_{\mathrm{Cu}}\right)
$$

where Zncom and Cucom denote the $\mathrm{Zn}(\mathrm{II})$ - and
Table 2 Calculated bond length ( $\mathrm{A})$ in the $\mathrm{Zn}(\mathrm{II})-\mathrm{ODPA}$ complex

\begin{tabular}{cccc}
\hline & & $\begin{array}{c}\text { Intra-hydrogen } \\
\text { bonding }\end{array}$ & $\begin{array}{c}\text { Inter-hydrogen } \\
\text { bonding }\end{array}$ \\
\hline $1-2$ & $=\mathrm{O}-\mathrm{Zn}$ & 2.18 & 2.23 \\
$1-3$ & $-\mathrm{O}-\mathrm{Zn}$ & 1.91 & 1.93 \\
$1-4$ & $-\mathrm{O}-\mathrm{Zn}$ & 1.90 & 1.93 \\
$1-5$ & $=\mathrm{O}-\mathrm{Zn}$ & 2.50 & 2.23 \\
\hline
\end{tabular}

$\mathrm{Cu}(\mathrm{II})$-extractant complexes. Figure 3 shows the relation between the energy difference in the heat of formation for $\mathrm{Zn}(\mathrm{II})$ - and $\mathrm{Cu}(\mathrm{II})$-extractant complexes $\left(\Delta H_{\mathrm{Zn}}-\Delta H_{\mathrm{Cu}}\right)$ and the length of spacer. These metal complexes were analyzed by the complex formulation, based on the results of extraction equilibrium (Eqs. (1) -(4)) obtained in the former section. The lowest energy structure of their complex will be discussed later. These calculated results support the conclusion that the bi-functional organophosphorus extractants possess a higher separation ability than that of mono-functional extractant, because the bi-functional extractants provide a high energy difference in the heat of formation for the metal complexes compared to that of 2EHPA, as shown in Fig. 3. Furthermore, we can predict the separation performance of bi-functional extractants, that is the effect of spacer length, by the energy difference. This means that we can design promising extractants that show a good selectivity towards a target metal ion by using the computational modeling. On the basis of the calculation (Fig. 3), the optimum spacer length is considered to be eight on the separation performance due to the largest energy difference and ODPA is expected to be the best extractant from the separation point of view. This prediction was supported by the extraction results (Fig. 2); ODPA shows better separation behavior than the other extractants. The extraction performance was found to be quite sensitive to the length of the spacer connecting the two functional groups. This methodology would be helpful for designing novel extractants because we can list up promising candidates for a target metal ion before synthesizing them. This results in reducing cost and time for the development of novel extractants.

Further, we discuss the optimal complex formation with the computational modeling. In the calculation, the complex formulation between a metal and extractant molecules was determined by the extraction equilibrium data. One of the important points was the mode of hydrogen bonding for the bi-functional organophosphorus extractants. The metal complex was unstable without hydrogen bonding formation between phosphonic acids. There are two modes for the hydrogen bonding: intra-bonding and inter-bonding. The intra-hydrogen bonding is formed between the phosphonic acids on both sides of the bi-functional extractants, and the inter-bonding is formed between extrac- 


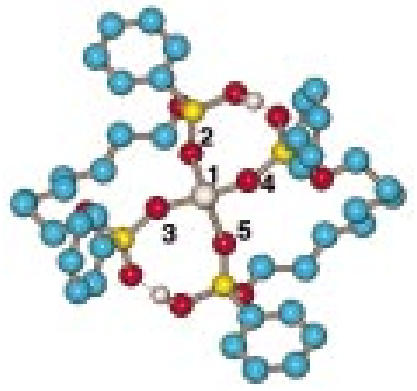

(a) Zn-ODPA Inter-Hydrogen Bonding

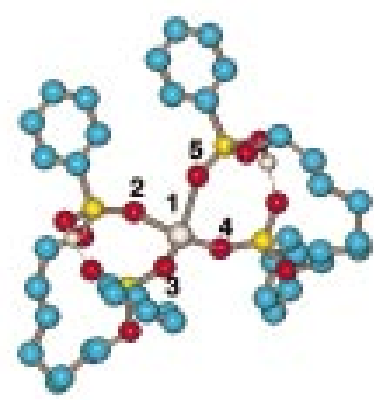

(b) Zn-ODPA Inter-Hydrogen Bonding

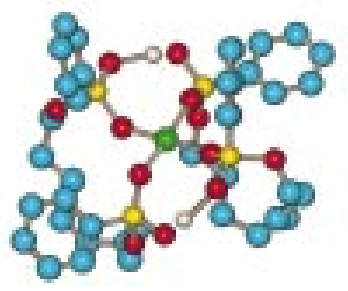

(c) Cu-ODPA Inter-Hydrogen Bonding

Fig. 4 The lowest energy structures of the $\mathrm{Zn}(\mathrm{II})-$ and $\mathrm{Cu}(\mathrm{II})$ ODPA complexes calculated by PM3-SMO. (red, oxygen; yellow, phosphorus; blue, carbon).

tants. Figures 4 (a) and 4(b) show the minimum energy structures for the $\mathrm{Zn}$ (II)-bi-functional complexes calculated by PM3-SMO: The picture in (a) was calculated by inter-hydrogen bonding mode and that in (b) was calculated by intra-hydrogen bonding mode. The $\mathrm{Zn}$ (II)-complexes were calculated by tetrahedral conformation. Bond lengths in the center part of the complex were obtained by the most stable structure, the values are summarized in Table 2. When the bi-functional extractant forms the intra-hydrogen bonding, the tetrahedral structure was deformed due to the unbalance in the bond lengths. As listed in Table 2 and shown in Fig. 4 (b), one of the four different bonds in the metal center is considerably long in the minimum energy structure. On the other hand, almost equivalent bonds were obtained by forming the inter-hydrogen bonding formation between bi-functional extractants. A similar

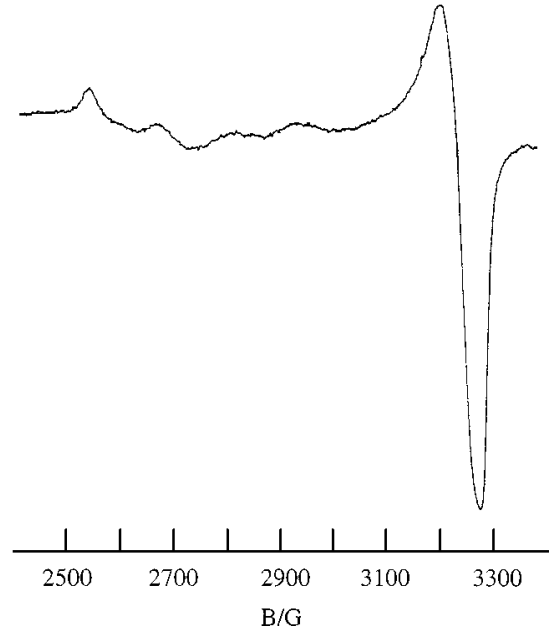

Fig. 5 Characteristic ESR spectrum of the $\mathrm{Cu}(\mathrm{II})-\mathrm{ODPA}$ complex in chloroform at $77 \mathrm{~K} . v=9.21598 \mathrm{GHz} .\left(g_{\perp}=2.08, g_{\|}\right.$ $\left.2.42, A_{\Perp}=112 \mathrm{G}\right)$

tendency was observed in the calculation of $\mathrm{Cu}(\mathrm{II})$ extractant complexes. In the $\mathrm{Cu}(\mathrm{II})$-complexes, we should consider a square planar conformation. From the view point of the heat of formation, the $\mathrm{Cu}$ (II) complex having the inter-hydrogen bonding provided a more stable $(3.6 \mathrm{kcal} / \mathrm{mol})$ structure. Figure 4 (c) exhibits the most stable structure for the $\mathrm{Cu}(\mathrm{II})$-bi-functional organophosphorus extractant complex. The four bond lengths forming the square planar structure are around $1.90 \AA$ ( $1.87-1.93 \AA)$. Figure 5 shows the ESR spectrum with four splittings for the $\mathrm{Cu}(\mathrm{II})-\mathrm{ODPA}$ complex. The ESR data also supports the square planar structure for the $\mathrm{Cu}(\mathrm{II})$ complex.

In this study, bi-functional organophosphorus extractants were synthesized and showed a good performance for $\mathrm{Zn}(\mathrm{II})$ and $\mathrm{Cu}(\mathrm{II})$ extraction. The extraction behavior was discussed with computational modeling for the minimum energy structures. A high separation ability for the bi-functional extractants was supported by the high energy difference in the heat of formation of the metal complexes calculated by computational modeling. Computational modeling was found to be very helpful for the design of novel extractants and prediction of their extraction performance.

We thank Professor Y. Hisaeda, Dr. H. Shimakoshi and Mr. S. Kitahara of Kyushu University for their helpful discussions about ESR spectra.

\section{References}

1. Y. Marcus, "Solvent Extraction Reviews", Vol. 1, Dekker, New York, 1971.

2. W. W. Schulz and J. D. Navratil, Sep. Sci. Technol., 19, 927 (1985)

3. Z. Asfari, C. Bressot, J. Vicens, C. Hill, J. F. Dozol, H. Rouquette, S. Eymard, V. Lamare and B. Tournois, Anal. Chem., 67, 3133 (1995). 
4. R. L. Miller, A. B. Pinkerton, P. K. Hurlburt and K. D. Abney, Solvent Extr. Ion Exch., 13, 813 (1995).

5. A. N. Turnov, V. K. Karandashev and V. E. Baulin, Solvent Extr. Ion Exch., 14, 227 (1996).

6. K. Ohto, K. Shiratsuchi, K. Inoue, M. Goto, F. Nakashio, S. Shinkai and T. Nagasaki, Solvent Extr. Ion Exch., 14, 459 (1996).

7. R. Chiarizia, E. P. Horwitz, P. G. Rickert and A. W. Herlinger, Solvent Extr. Ion Exch., 14, 773 (1996).

8. Y. Sasaki and G. R. Choppin, J. Radioanal. Nucl. Soc., Articles, 207, 383 (1996).

9. O. Navratil, P. Sladek, A. Tokarova, E. Herrmann and M. Nouaman, Collect. Czech. Chem., 62, 620 (1997).

10. R. Chiarizia, A. W. Herlinger, Y. D. Cheng, J. R. Ferraro, P. G. Rickert and E. P. Horwitz, Solvent Extr. Ion Exch., 16, 505 (1998).

11. N. Reynier, J. F. Dozol, M. Saadioui, Z. Asfari and J. Vicens, Tetrahedron Lett., 39, 6461 (1998).

12. M. Goto, S. Matsumoto, K. Uezu, F. Nakashio, K. Yoshizuka and K. Inoue, Sep. Sci. Technol., in press (1999).

13. R. D. Hancock, A. E. Martell, D. Chen, R. J. Motekaitis and Derek McManus, Can. J. Chem., 75, 591 (1997).

14. M. Lauterbach, E. Engler, N. Muzet, L. Troxler and G. Wipff, J. Phys. Chem. B, 102, 245 (1998).

15. P. Comba, K. Gloe, K. Inoue, T. Krüger, H. Stephan and K. Yoshizuka, Inorg. Chem., 37, 3310 (1998).

16. V. Lamare, J. F. Dozol, F. Ugozzoli, A. Casnati and R.
Ungaro, Eur. J. Org. Chem., 1559 (1998).

17. H. Watarai, M. Gotoh and N. Gotoh, Bull. Chem. Soc. Jpn., 70, 957 (1997)

18. J. J. P. Stewart, MOPAC93: A Molecular Orbital Package; JCPEP081; Stewart Computational Chemistry: Colorado Springs, CO, 1993.

19. F. Nakashio, K. Kondo, A. Murakami and Y. Akiyoshi, J. Chem. Eng. Jpn., 15, 274 (1982).

20. T. B. Pierce and P. F. Peck, Analyst [London], 88, 217 (1963).

21. C. Djordjevic and H. Gorican, J. Inorg. Nucl. Chem., 28 , 1451 (1966).

22. C. F. Coleman and J. W. Robby, Solvent Extraction Reviews, 1, 63 (1971).

23. Z. Kolaric, G. Koch and W. Kuhn, J. Inorg. Nucl. Chem., 36, 905 (1974).

24. G. F. Vandegrift and E. P. Horwitz, J. Inorg. Nucl. Chem., 39, 1425 (1977).

25. P. R. Danesi and C. Cianetti, Sep. Sci. Technol., 17, 969 (1982).

26. K. Yoshizuka, Y. Sakamoto, Y. Baba, K. Inoue and F. Nakashio, Ind. Eng. Chem. Res., 31, 1372 (1992).

27. R. D. Hancock and A. E. Martell, Chem. Rev., 89, 1875 (1989).

(Received March 1, 1999)

(Accepted April 12, 1999) 